\title{
THE TRADITIONAL BIO-MEDICAL DICHOTOMY IN SEARCH OF A COMMON GROUND
}

\author{
ML ARTHUR
}

\begin{abstract}
Differences between bio-medical and traditional systems are regarded as irreconcilable by many, including members of the medical, nursing and allied professions. This article explores those areas in which emphasis on difference has resulted in an exclusion of the common basis from which culturally determined areas of human and health behoviours are derived. As long as difference is emphasized to the exclusion of attempts to find a common ground, the dichotomy between traditional and bio-medicine will remain.
\end{abstract}

\section{OPSOMMING}

Baie mense, insluitende lede van die mediese, verpleeging en verwante professies, beskou verskille tussen die bio-mediese en tradisionele gesondheidssisteme as onversoenlik Hierdie artikel gebiede ondersoek waarin klem op verskille veroorsaak het dat die gemeenskaplike basis van kulturele bepalende menslike en gesondheidsgedrags patrone ontstaan het. Solank verskille beklemtoon word tot die uitsluiting van pogings om 'n gemeenskaplike grondslag te ontdek, sal die digotomie tussen biomediese en tradisionele gesondheidssisteme bly bestaan.

\section{INTRODUCTION}

In the complex society that is South Africa today, a highly sophisticated technological medical system co-exists with traditional beliefs and practices concerning health and ill-health. The problem of accommodation between both systems arises and becomes a question of major imporiance (Hammond-Tooke, 1989:12): not only to the health care system as a whole, but also in respect of the effective implementation of primary health care services where the principles of accessibility, affordability, acceptability and equity of services are also taken into account.

Every society develops "- an entire set of strategies and traditions that are relied upon to maintain and restore well-being (Good, in: Gesler, 1989:129). These features are embedded in the health and/or medical systems of every human community. All medical systems are made up of a pattern of cultural traditions and social institutions which evolve over time as a result of deliberate human activities to enhance health (Forster, 1983:17). Illness or the human experience of disease comprises "- a socially constructed phenomenon located within a socially organized content" Anderson, 1986:1277).

Health care workers, as well as those to whom health care is directed, are cultural beings, interpreting and attributing meaning to their world in accordance with their cultural, social and personal experiences. Professional health workers, regardless of cultural affiliation tend to share the biomedical or allopathic perspective of health and ill-health (Arthur, 1995:8). Conversely, the majority of people in Third World communities turn to traditional medicine during times of ill-health (Tahzib \& Daniel, 1986:203).

The distinction between 'traditional' and 'modern' medicine is absolutely arbitrary when the personal, interpersonal and community variables affecting interchanges between healers and patients are considered within the total healing context. However, it is a generally accepted useful distinction to describe the modern, Westem-orientated, biomedical structural system in contrast to more local, culturally relativistic, functionally strong, humoral traditional approaches (Edwards, 1986:1273).

\section{THE TRADITIONAL - BIOMEDICAL DICHOTOMY}

"Traditional healing rests upon a religious frame of reference - (Dovey \& Mjingwana, 1985:77). Religion forms the fabric of traditional African Life, being closely connected to all the thoughts and activities of the people. Ideas of health and illness are an integral part of a religious system in which beliefs in a life after death play an important role (Jansen, 1982:106;-Hammond-Tooke, 1989:46,53). In these terms, and according to traditional African cosmology, the universe comprises two worlds: the world in which man lives and the world of the ancestral spirits. As spiritual beings, the ancestral spirits are invisible members of society who care for and carry responsibility for the actions of their descendents. Health, prosperity and misfortune are attributed to the continued goodwill or wrath of the ancestors by traditional communities (Mdleleni, 1987:42). Natural conditions, as causes of disease, are not discounted.

More specifically, traditional medicine may be defined as the sum total of all knowledge and practices, whether explicable or not, used in the diagnosis, prevention and elimination of physical, social or mental imbalance. The traditional medical context relies exclusively on medical experience and observation handed down through the generations, whether verbally or in writing (WHO, in: Wolffers, 1990:5). The traditional healer, in turn, is a person recognised by the community as being competent to provide health care through the use of vegetable, animal and mineral substances as well as the utilisation of certain methods based on the social, religious and cultural background of the community. The practices are integrated with the prevalent knowledge, attitudes and beliefs concerning physical, social and mental well being and the causation of disease and disability (WHO, in: Haram, 1991: 167).

By way of contrast, the principles on which biomedicine rest are based on a scientific approach (Leininger, 1978:190). Modern medicine regards the body in purely mechanistic terms (Hammond-Tooke, 1989:145) and includes notions that life processes can be controlled by mechanised and engineered interventions (Boyle \& Andrews, 1989:28). The biomedical model accepts the doctrine of specific aetiology, postulating that specific diseases are caused by specific organisms and conditions. Simple cause and effect relationships are proposed in keeping with the reductionist view of nature in which interactions of discrete entities are involved in a linear causal fashion (Engel. in: Webster, 1989:23). Therefore, disease is regarded as being caused by natural or unnatural factors and treatment is geared towards controlling or removing the cause in a rational and specific manner (Cockerham, 1986:6, Engel, in: Webster, 1989:24)

The emphasis in modern medicine is on the formulation of exact laws (Webster, 1989:21). The connections between health and disease, being mechanistic and scientific, are governed by physical, chemical and biological laws sought within the parameters of the system itself. Laws embrace concepts such as viruses, cell sub-division and chemical imbalances. The possibility of influences originating from non-scientific sources is vigorously denied. In the search for cause and effect, outside influences stemming from spiritual forces are 
considered unscientific and unthinkable Biomedical practice is, therefore, quite separate from religion (Hammond-Tooke, 1989: 18, 145-146).

It is an undisputed fact that cultural patterns do not occur in isolation, but are integrated within the complex network of values and beliefs that make up the culture of every society, hence the gulf between the so-called scientific and magico-religious health systems. However, what is the extent of the difference and to what extent are these differences mutually exclusive?

\section{MEDICAL SYSTEMS CONSTITUTE AN NTTEGRAL PART OF THE CULTURE OF EVERY SOCIETY}

It has been rightly stated that we become aware of our own cultures only when confronting the culture of others. Difference is noteworthy: it marks the divide between them and us. That which men and women of all nationalities hold in common goes unmarked. Difference is particularly marked when comparisons are made between traditional and biomedical practice. The question posed is: "Is there a common ground?"

In response to this question on philosophical grounds, it may be asked "do we not all share a common humanity and do not all healers share the same goal to relieve pain and suffering, to cure the disease if possible and to comfort the sufferer?" (Gumede, 1990:153). The healer may even include some explanation as to the cause of the diseases. However, these are certainly not arguments that will carry weight with health practitioners whose feet are firmly rooted in the everyday reality of treating patients or communities.

It therefore becomes necessary to examine the various descriptive labels that have been attached to traditional and biomedicine as researchers in disciplines such as anthropology, ethnology, ethnomedicine and medical sociology attempt to describe and draw comparisons between the two systems.

\section{'Open' versus 'Closed' Systems of Medical Care}

Biomedicine has always been viewed as an 'open' or inclusive system of health care in the sense of being open to change and progress in the light of new scientific findings and technological advances, while traditional cultures have been described as closed to outside influences.

Haram (1991:167) has shown that traditional Tswana medicine, through its traditional practitioners, displays both 'openness' and 'closedness' when confronted with a new body of knowledge and practice. On exposure to external cultural elements, new medical knowledge can be fitted into already existing categories of knowledge, may be considered useful for specific sorts of ailments, can be modified into existing frameworks in a meaningful way or be rejected. In other words, it may be deduced that traditional medicine is an open system to the extent that it allows new knowledge to be assimilated, without replacing existing notions of 'reality' or 'truth', but is closed in so far as existing truths are monitored or new practices rejected on grounds of incompatibility with the existing system.

The same principles hold good for biomedicine. In South Africa, professional co-operation between the official biomedical health system and professionals representing alternative health systems was forbidden by law until the end of 1994. A tendency exists to ignore or define as illegal or inappropriate those experts who use alternate assumptions, rationales and methods and operate outside the scientific parameters recognised by the biomedical system (Shuval, 1981: 340). Exclusivity is hereby maintained (Arthur, 1995:118). To this extent biomedicine has been closed in respect of alternative medical systems but is open to new elements from outside the system to the degree that the new knowledge is compatible with the existing system.

It may be concluded that traditional and biomedicine are characterised by both openness and closedness. The point of departure lies in definitions of 'truth' or 'reality' as embedded in a particular world view - in this case:

Scientific versus Non-Scientific Systems of Health Care

Biomedicine is described as scientific and empirical and traditional medicine as non-scientific (Gumede, 1990:154). The biomedical approach is that disease is a natural phenomenon subject to investigation by scientific methods (Coe, 1978:131) while traditional medicine tends to be built upon accumulated,as opposed to scientific, proof (Elling, 1981:96). In addition, many religious, economic, social, philosophical and other non-medical factors determine the nature and practice of traditional African medicine.

While this generalisation holds good in most instances, it should be noted that biomedicine shares the quality of accumulated understandings with traditional medicine (Elling, 1981:96) especially in respect of the continued use of folk medicine in First World societies. Folk medicine is not the prerogative of traditional medicine. Folk remedies, constituting the basis for prevention or treatment of ailments, are found in all household medicine cabinets. Today "___ popular medicine is in a sense commercial folk medicine" (Spectar, 1985:29-30).

Furthermore, integration of medical beliefs and practices with other aspects of culture is never a perfect fit in either First or Third World societies. The implication is that the degree to which segments of any population are aware of the totality of their medical belief system will vary (Coe, 1978:131).
The notion of scientific versus non-scientific medical systems is closely linked to questions surrounding the following conceptualisation:-@HEAD3 = Naturalistic versus Magico-Religious Systems of Medical Care

Biomedicine, based on logico-deductive procedures of diagnosis, excludes the mystical and religious (Hammond-Tooke, 1989:37; 146). A world view based on supernatural and other belief systems is incompatible with, alien and incomprehensible to, modern-sector medical practitioners (Green, 1988:1126). However, because the esoteric qualities of biomedical definitions of disease are not always understood by First World communities, acceptance of the system in itself becomes an act of faith.

A mechanistic naturalistic view of disease carries the implication that causes of ill-health stemming from the social environment, together with their associated symbolic significance and meaning, are disregarded or misunderstood (Ferreira, 1987: 141). At the same time, it cannot be denied that religion remains a social reality regardless of First or Third Worid affiliation. People continue to seek the meaning of life events at levels above those of mechanistic laws. Both religion and magic seem to satisfy an eternal 'psychic' or 'metaphysical' need of mankind for integration and harmony. Religion and magic are both logical in their own way, although not on the basis of empirical premises. Evidence is found of magico-religious systems in Western cultures. The practice of laying on of hands and prayer is to be found in the evangelical and more orthodox Christian religions and co-exists with the medical system. Religion remains a social reality regardless of First or Third World affiliation.

While the philosophy of disease causation in traditional medicine rests on the idea of illness as a consequence of disharmony within the cosmic order (Capra, 1982:335), traditional medication includes many successful treatments that can be explained by Western medicine in a rational and scientific way (Coe, 1978:132).

To view traditional medicine as magico-religious and biomedicine as non-religious and scientific becomes increasingly problematic, if one considers that many herbalists, bonesetters and midwives operate in a very instrumental and purely functional fashion, while both divination and related treatments could be analysed in terms of psychotherapeutic variables. A significant body of research in biomedicine reveals the positive results of the placebo effect (Feierman, 1985: 106). It is an error to read religious meanings into forms of healing that are not religious or to reduce the religious meaning of sacred healing to mechanical or clinical significance (Csordas \& Kleinman, 1990: 14; Rappaport, 1980:82).

In every society prevention of disease and treatment of illness follow more or less logically from beliefs about causation. Again the question arises as to whether treatments across the cultural divide are mutually exclusive. 
Limited versus Holistic Systems of Medical Care

A mechanistic view of the body precludes incorporation of philosophical and existential issues. Treatment is focused on what is wrong. It is symptom or disease specific (Rappaport, 1980:83) in respect of the rational and scientific. Conversely, traditional practitioners focus on questions concerning 'why' and address 'anxieties' associated with ill-health in efforts to treat symptoms. The traditional model incorporates a multiple factor concept of disease causation and thus treatment (Rappaport, 1980:83), in which there is no differential between body, mind and spirit. For these reasons biomedical systems are frequently regarded as limited in nature while those of traditional systems as holistic in character.

In reality, the dichotomy is not so clear cut. Epidemiologists endorse the multiple factor concept of disease causation and advances in fields of study such as psychology and sociology have led biomedical practitioners to pay more attention to the social and emotional variables of disease causation. Modemisation and rural-urban drift are making it hard for traditional practitioners to know the background of their patients intimately and are no longer able to play a wider social role as in traditional community life. Many are beginning to adopt some of the practices of modem health care as well as organising themselves into professional bodies (De Jong, 1991:8). Increasingly, biomedical practitioners are seeking to expand their skills in areas more commonly associated with the complementary health systems.

\section{Scientific-Technological versus \\ Non-Scientific Non-Technological Diagnosis and Treatment}

The conventional distinction between scientific and technological and non-scientific and non-technological is particularly apparent in respect of diagnosis and treatment procedures. At the same time recognisable artifacts are as essential for the Western clinician as for the traditional practitioner. Symbols, such as impressive consulting rooms, stethoscopes, diplomas, examination couches and white coats, all constitute part of a scientific image of power and authority. For the traditional practitioner artifacts such as masks, animal horns, bones and drums all serve to project the desired image of charisma (Rappaport, 1980:91) Difference? Yes! However, in what may be referred to as the 'Trappings of the Trade', the initiates into the respective medical systems will recognise the uniforms and equipment representing long years of training, whether at university or as an apprentice called to the profession by the ancestral spirits. They will have certain expectations concerning diagnostic tools and treatment and be in no doubt about the status of the practitioner. The perceived potency of the medical practitioner, regardless of world view, remains an essential feature of the diagnosis and treatment of disease in all medical systems.
Diversity yes, but in communality all men are attuned to the symbols provided by their culture.

While the above discourse notes the point at which traditional and biomedicine can no longer be said to be mutually exclusive in respect of culturally determined areas of health behaviour, no tangible evidence has been presented yet to demonstrate that an operational common ground exists between the two systems.

\section{In search of a Common Ground}

An increasing number or authors refer to the pluralistic nature of all medical systems in the world today (Hammond-Tooke, 1989:1512; Wolffers, 1990:6; Ulin and Segall, 1980: 1-58). Patients' participation in the respective medical systems sometimes overlap, coincide or are mutually exclusive. The vast body of literature in the field of ethnomedicine, extended by researchers to include biomedicine, reveals that regardless of the apparent infinite variety of approaches towards medical practice, structure emerges as the volume of information is classified. From the midst of detailed difference, similarities begin to emerge from which relatively few general principles can be extrapolated. The common elements are founded on the principle of limited possibilities. There are only so many ways in which a medical practitioner can acquire knowledge and skills and so many ways in which a patient can become ill and be treated (Foster, 1983:17-18).

Although bio- and traditional medicine are based on different paradigms, it is important to understand that their practitioners do not constitute homogenous groupings. Each has many different specialities and treats different types of illness. A simple analysis in which the biomedical system is broken down into the components of matemal and child health, pharmaceutical, surgical and preventive services and that of traditional medicine into traditional midwifery, herbalism, ritual manipulations and preventive and prescriptive taboos, reveals a definite common ground between the two systems. Herbalism corresponds with pharmaceutical services, traditional midwifery finds its counterpart in the area of child and matemal health. Surgery correlates with manipulative rituals such as bone-setting, blood letting and removal of foreign objects and finally, taboos are related to preventive medicine (Spring, 1980:58). Furthermore, it is possible to extend the components of any health system indefinitely and seek counterparts in other systems.

\section{CONCLUSION}

Traditional and biomedical systems should not be viewed as polar opposites for a synthesis of both the modem and the traditional is feasible on grounds of the relative openness of all social systems. Here lies the possibility of a common meeting ground for the sharing of knowledge and skills for the benefit of patients or clients as we all strive towards "Health for All by the Year 2000."

An understanding of the common experience of cultural meaning and the dangers inherent in labeling 'others' on grounds of manifest difference opens the way for health workers to narrow the gap in the search for a common ground by:

* identifying 'own' and 'others' areas of openness and closedness with a view to learning and educating through proceeding from the known to the unknown in reciprocal interactional encounters;

* avoiding snap judgments conceming so-called scientific and non-scientific or naturalistic and magico-religious systems of health care and analysing the respective strengths and weaknesses of each. Such an approach lends itself to reinforcing the strengths of the respective systems and permits of modification of specific knowledge and practices within the framework of the prevailing cultural value system to the benefit of the health of communities.

* ensuring that holistic health care is delivered through maximising the use of all health resources within a community. This outcome will not be achieved by assuming that this or that system delivers or does not deliver holistic care, but by active and ongoing community participation characterised by effective interaction between people of the same and different socio-cultural and health backgrounds.

\section{REFERENCES}

Anderson, J.M (1986): Ethnicity and Illness Experience: Ideological Structures and the Health Care Delivery System. Social Science and Medicine. Vol. 22. No. 11 (1277-1283)

Arthur, M.L. (1995): Health Education in Cross Cultural Encounters. An Agogical Perspective. Unpublished D.Ed. Thesis. Pretoria: Unisa.

Capra, F. (1982): The Tuming Point: Science, Society and the Rising Culture. London: Flamingo.

Cockerham, w.C. (1980: Medical Saciology. Engelwood Cliffs: Prentice Hall.

Coe, R.M. (1978): Sociology of Medicine, New York: McGraw Hill.

Csordas, T.J. \& KJeinman, A. (1990): The Therapeutic Process. Johnson, T.M. \& Sargent, C.F. (eds.). Medical Anthropology: Contemporary Theory and Method. New York: Praeger.

Dovey, K \& Mjingwana, R. (1985): Psychology, Religion and Healing: The 'Amagquira' in Traditional Xhosa Society. Theoria. Vol. 64 (77-83).

Edwards, S.D. (1986): Traditional and Modern Medicine in South Africa: A Research Study. Social Science and Medicine. Vol. 22, 11 (1273-1276). 
Elling, R.H. (1981): Political Economy, Cultural Hegemony and Mixes of Traditional and Modern Medicine. Social Science and Medicine. Vol 15A, No.2 (89-99).

Forster, G.M. (1983): An Introduction to Ethnomedicine. Bannerman, R.H., Burton, J. \& Wen-Chieh, C. (eds.). Traditional Medicine and Health Care Coverage. Geneva: WHO.

Gesler, W.M. (1989): Book Review of Good, C.M. 1987. Ethnomedical Systems in Africa. Geographical Reviews. Vol.79, No. 1 (128-130).

Green, E.C. (1988): Can Collaborative Programs Between Biomedical and African Indigenous Health Practitioners Succeed? Social Science and Medicine. Vol. 27, No. 11 (1125-1130).

Gumede, M.V. (1990): Traditional Healers: $A$ Medical Doctor's Perspective. Cape Town: Skotaville.
Hammond-Tooke, D (1989): Rituals and Medicines: Indigenous Healing in South Africa. Johannesburg: AD. Donker

Jansen, F.E. (1982): An investigation into the Scope of Medical Anthropolology and the Possibility of Improving the Effectiveness of Cross-Cultural Western Medical Services for South African Blacks. Unpublished M.A. Dissertation. Port Elizabeth: Port Elizabeth University.

Mdleneni, T. (1987): Spirit Possession and Spirit Healing. Odyssey. June/July (42).

Shuval, J.T. (1981): The Contribution of Psychological and Social Pbenomena to an Understanding of the Aetiology of Disease and Illness. Social Science and Medicine. Vol 15A, No. 3 (337-342).

Spectar, R. E. (1991): Cultural Diversity in Health and Jlness. Norvolk: Appleton and Lange.

Tahzib, F. \& Daniel, S.O. (1986): Traditional Medicine and Modern Curriculum. The Lancet. No. 8500 (203-204).
Webster, P. (1989): 'Multiple Realities': Towards Integrating the Different Mental Health Models. Unpublished M.A. Dissertation. Johannesburg: Rau.

Wolffers, I. (ed.). (1990): The Role of Traditional Medicine in Primary Health Care. Amsterdam: V U University Press.

MAVIS LORRAINE ARTHUR D.Ed (UNISA); M.Ed (UNISA); D.T.E. (UNISA);

BA Nursing (UNIVERSITY OF PRETORIA); N.Dip: Public Health Nursing (WITWATERSRAND TECHNICAL COШEGE); Midwifery Part I \& Part II (UNITED KINGDOM)

SCHOOL OF HEALTH TECHNOLOGY: TECHNIKON WITWATERSRAND 